\title{
Microstructure and Mechanical Properties of Gypsum Composites Reinforced with Recycled Cellulose Pulp
}

\author{
Magaly Araújo Carvalho ${ }^{\mathrm{a} *}$, Carlito Calil Júnior ${ }^{\mathrm{a}}$, Holmer Savastano Junior, \\ Rejane Tubino ${ }^{\mathrm{c}}$, Michele Tereza Carvalho ${ }^{\mathrm{d}}$ \\ ${ }^{a}$ Escola de Engenharia de São Carlos, EESC/USP - São Carlos - SP, Brazil \\ ${ }^{\mathrm{b}}$ Faculdade de Zootecnia e Engenharia de Alimentos, FZEA/USP, Pirassununga - SP, Brazil \\ ${ }^{ }$Escola de Engenharia Civil, EEC/UFG - Goiânia - GO, Brazil \\ ${ }^{\mathrm{d}}$ Furnas Centrais Elétrica - Goiânia - GO, Brazil
}

Received: May 20, 2007; Revised: October 17, 2008

\begin{abstract}
The use of waste fibers for the reinforcement of brittle matrices is considered opportune for the sustainable management of urban solid residues. This paper examines the microstructure and mechanical properties of a composite material made of gypsum reinforced with cellulose fibers from discarded Kraft cement bag. Two different kinds of gypsum were used, natural gypsum (NG) and recycled gypsum (RG), both with an addition of $10 \%$ by mass of limestone. For the production of samples, slurry vacuum de-watering technique followed by pressing was evaluated revealing to be an efficient and innovative solution for the composites under evaluation. The composite was analyzed based on flexural strength tests, scanning electron microscopy (SEM) imaging, secondary electron (SE) detection, and pseudo-adiabatic calorimetry. The morphology of the fractured surfaces of flexural test samples revealed large gypsum crystals double the original size surrounding the fibers, but with the same overall aspect ratio. Natural fibers absorb large amounts of water, causing the water/gypsum ratio of the paste to increase. The predominance of fiber pullout, damaged or removed secondary layers and incrusted crystals are indicative of the good bonding of the fiber to the gypsum matrix and of the high mechanical resistance of composites. This material is a technically better substitute for the brittle gypsum board, and it stands out particularly for its characteristics of high impact strength and high modulus of rupture.
\end{abstract}

Keywords: gypsum-cellulose composite, waste fibers, recycled pulp, mechanical properties

\section{Introduction}

The productive chain of the civil construction industry has represented one of the activities of the society which has interfered most directly with the environment. It is a large consumer of resources (materials/energy), highly polluting (emission of $\mathrm{CO}_{2}$ ), and a generator of residues. Therefore, in the search of a sustainable construction, attentions turn to research on agglomerates of minor energetic consumption and to the adequate use of industrial and agroindustrial waste. When compared to cement and lime, the industrial process of plaster production issues less anhydrous carbon $\left(\mathrm{CO}_{2}\right)$ and reveals the lowest energy consumption, being thus regarded as "green agglomerate". However, studies carried out in this country indicate that the waste indexes of this material reach around $45 \%$ of the total dough ${ }^{1}$.

The combination of inorganic binder material such as gypsum with waste fibers has been considered an interesting option for material recycling and has been used for structural overlays and ceilings in several parts of the world ${ }^{2}$. The main advantage of using natural fibers is their high energy-absorbing capacity resulting from their low modulus of elasticity. When fiber pullout predominates over fracture, fiber-matrix bonding is considered the main factor influencing the composite's toughness ${ }^{3}$, ensuring the possibility of post-fracture work, which is an important characteristic in civil construction. The high availability of noncommercial fiber waste ${ }^{4}$, or low cost fibers, may constitute a good opportunity for a serious proposal of sustainable methods for producing low cost gypsum-fiber components for civil construction. Compared to composites reinforced with virgin fibers, composites containing recycled fibers have presented good mechanical properties. Research by Savastano Jr. et al. ${ }^{5}$ showed that banana pulp, Eucalyptus grandis and sisal wastes presented satisfactory adhesion in fiber-cement composites, reaching a flexural strength of 15.5 to $16.5 \mathrm{MPa}$. The sensitivity of natural fiber to the alkaline environment produced by the hydration of standard Portland cement with a $\mathrm{pH}$ of around 13 has led researchers ${ }^{6,7}$ to suggest the use of gypsum, with its $\mathrm{pH}$ of 7 to 8 , as an adequate binder for matrices reinforced with alkaline-sensitive vegetal fibers.

The aim of this research was to examine the influence of cellulose pulp on the mechanical properties of construction gypsum. Moreover, the stirring vacuum de-watering process was evaluated for the production of composites. Savastano Jr Warden and Coutts ${ }^{8}$ previously studied and developed this technique for the production of composite materials based on cement matrices. The hydration kinetics and morphology of hardened paste are important parameters in understanding the material.

The hydration kinetics of gypsum occurs by an exothermic process of energy released in the form of heat. The microstructure of the paste changes in response to parameters such as hydration conditions, mixing water temperature, gypsum properties, and the application of chemical additives ${ }^{9}$. When gypsum is mixed with water, the supersaturated solution composed of $\mathrm{SO}_{4}{ }^{2-}$ and $\mathrm{Ca}^{2+}$ ions precipitates into a needle-like crystalline network in a matter of minutes. Hardening be- 
gins at the instant when the temperature gradient exceeds $0.1^{\circ} \mathrm{C} / \mathrm{min}$ and ends when the temperature reaches its maximum ${ }^{10}$. The reactivity of the hydration can be quantified based on calorimetric curves, i.e., on the velocity of heat radiation.

For the morphological analysis, fractured gypsum surfaces, with and without addition of cellulose pulp were prepared and visualised through a scanning electron microscope (SEM). The kinetics of the hydration process was assessed using a pseudo-adiabatic calorimeter.

\section{Experimental}

\subsection{Materials}

The materials used in this work were natural gypsum (NG), recycled gypsum (RG), limestone, Kraft paper pulp from discarded cement bags (cel-cb), and water (Figure 1).

The natural gypsum (NG) used in this research is a commercial product from the region of Grajaú, Maranhão state, Brazil, commercially available on the construction materials market, while the recycled gypsum $(\mathrm{RG})$ originated from construction debris (dehydrated at $85^{\circ} \mathrm{C}$ in a fan-assisted oven and milled for 20 minutes in ball-type mill). Table 1 lists the chemical composition and physical properties of the materials.

Calcium sulfates are the main components of gypsum. When treated with a diluted chloric acid solution they are expressed as sulfuric anhydride $\left(\mathrm{SO}_{3}\right)$ and calcium oxide $(\mathrm{CaO})$, while impurities such as quartz are expressed as insoluble residues (RI). Clay minerals are quantifiable as aluminum $\left(\mathrm{Al}_{2} \mathrm{O}_{3}\right)$ and iron $\left(\mathrm{Fe}_{2} \mathrm{O}_{3}\right)$ oxide contents. Table 1 indicates that the products used here were of high purity grade, i.e., $\mathrm{SiO}_{2}+\mathrm{RI}+\mathrm{Al}_{2} \mathrm{O}_{3}+\mathrm{Fe}_{2} \mathrm{O}_{3}<1.5 \%$.

With regard to the calcium oxide content $(\mathrm{CaO}=38.65 \%)$, the product fell within the standard limits. The sulfuric anhydride did not

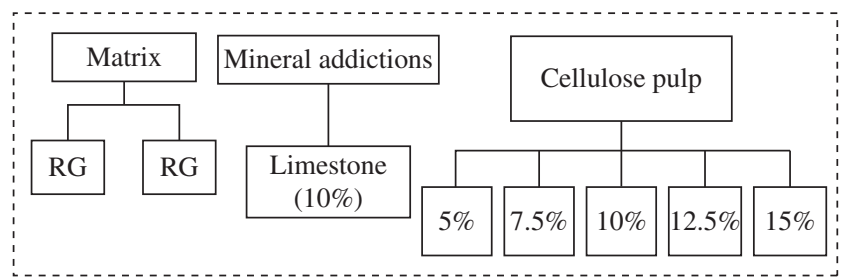

Figure 1. Flowchart of samples. meet the Brazilian standard ${ }^{11}$, but lay within the limits established by the British ${ }^{12}$ and French ${ }^{13}$ standards, which admit minimum values of respectively. Cincotto et al. ${ }^{14}$ analyzed 15 different types of Brazilian gypsum and concluded that a minimum value of $50 \%$ for $\mathrm{SO}_{3}$ is sufficient to ensure gypsum quality.

Limestone is a raw material commonly employed by cement and fiber-cement manufacturers. The limestone used here came from the municipality of Cesarina, Goiás state, Brazil, and was supplied by Eternit Ltda. Its probable chemical composition is given in Table 2.

The limestone used here - an inert additive that facilitates drainage of the paste during molding - had a low fineness factor, with $67.5 \%$ of the particles sifting through a 100 mesh sieve, $18 \%$ through a 200 mesh sieve and $0.7 \%$ through a 325 mesh sieve. $17.3 \%$ of the particles were retained in the latter sieve and were added to the gypsum mass at a percentage of $10 \%$.

The cellulose fibers of cement bag (cel-cb) were dispersed with water in a hydropulper, a giant industrial blender that separates particles, blending them into a homogeneous pulp. This preparation took place in the following stages: at a concentration of $6 \mathrm{~g}$ of Kraft paper per liter of potable water, the material was processed for 30 minutes (this period was established during the pulping process, since it resulted in the best pulp dispersion quality). After this dispersion process, the excess was drained off through a sieve and a fine strainer (causing the pulp to reagglomerate). Lastly, the pulp, with a moisture content of about $75 \%$, was again mixed for 5 minutes in a low speed laboratory electric mixer and stored in plastic bags in a refrigerator.

Table 2. Chemical composition of the limestone.

\begin{tabular}{lc}
\hline \multicolumn{1}{c}{ Properties } & Content $(\%)$ \\
\hline Loss to Fire & 36.02 \\
Silicon Dioxide $\left(\mathrm{SiO}_{2}\right)$ & 14.67 \\
Calcium Oxide $(\mathrm{CaO})$ & 46.07 \\
Magnesium Oxide $(\mathrm{MgO})$ & 0.53 \\
Aluminum Oxide $\left(\mathrm{Al}_{2} \mathrm{O}_{3}\right)$ & 0.90 \\
Iron Oxide $\left(\mathrm{Fe}_{2} \mathrm{O}_{3}\right)$ & 0.87 \\
\hline Total Alkalis & Content $(\%)$ \\
\hline Sodium Oxide $\left(\mathrm{Na}_{2} \mathrm{O}\right)$ & 0.07 \\
Potassium Oxide $\left(\mathrm{K}_{2} \mathrm{O}\right)$ & 0.09 \\
Alkaline Equivalent & 0.12 \\
\hline
\end{tabular}

Table 1. Chemical and physical characteristics of the natural (NG) and recycled (RG) gypsum.

\begin{tabular}{|c|c|c|c|c|c|c|}
\hline \multicolumn{2}{|c|}{ Properties } & \multicolumn{3}{|c|}{ Standards - limits } & \multirow{2}{*}{$\begin{array}{c}\text { Natural } \\
\text { gypsum (NG) }\end{array}$} & \multirow{2}{*}{$\begin{array}{c}\text { Recycled } \\
\text { gypsum (RG) }\end{array}$} \\
\hline & & $\mathrm{NBR}^{[9]} 13207$ & $\mathrm{BS}^{[10]} 1191 / 73$ & $\mathrm{NFB}^{[11]} 12300 / 63$ & & \\
\hline \multirow{5}{*}{$\begin{array}{l}\text { Chemical } \\
\text { analysis }(\%)\end{array}$} & Water of crystallization & 4.2 to 6.2 & - & - & 7.91 & 10.65 \\
\hline & $\mathrm{CaO}$ & $>38$ & $\geq 23.3$ & - & 38.65 & 35.94 \\
\hline & $\mathrm{SO}_{3}$ & $>53$ & $\geq 35$ & $>45$ & 52.08 & 49.61 \\
\hline & $\mathrm{Al}_{2} \mathrm{O}_{3}+\mathrm{Fe}_{2} \mathrm{O}_{3}$ & - & - & - & 0.41 & 0.45 \\
\hline & $\mathrm{SiO}_{2}+\mathrm{RI}$ & - & - & - & 0.65 & 0.85 \\
\hline \multirow{3}{*}{$\begin{array}{l}\text { Calculated } \\
\text { chemical } \\
\text { percentage }(\%)\end{array}$} & $\left(\mathrm{CaSO}_{4} \cdot{ }_{2} / \mathrm{H}_{2} \mathrm{O}\right)$ & - & - & - & 92.22 & 91.12 \\
\hline & $\left(\mathrm{CaSO}_{4}\right)$ & - & - & - & - & - \\
\hline & $\left(\mathrm{CaSO}_{4} \cdot 2 \mathrm{H}_{2} \mathrm{O}\right)$ & & & & 3.3 & 4.6 \\
\hline $\mathrm{pH}$ & - & - & - & - & 7.96 & 8.12 \\
\hline \multirow{3}{*}{$\begin{array}{l}\text { Physical } \\
\text { properties }\end{array}$} & Specific mass $\left(\mathrm{g} \mathrm{cm}^{-3}\right)$ & \multicolumn{3}{|c|}{$>700.00$} & 2.50 & 2.56 \\
\hline & Unit mass $\left(\mathrm{kg} \cdot \mathrm{m}^{-3}\right)$ & \multicolumn{3}{|c|}{$>1.10$ (thick foundry gypsum) } & 649.00 & 504.73 \\
\hline & Thinness factor & \multicolumn{3}{|c|}{$<1.10$ (thin foundry gypsum) } & 0.72 & 1.54 \\
\hline
\end{tabular}


The fibers were characterized in a Galai CIS-100 particle analyzer in the Federal University of Viçosa's Pulp and Paper Laboratory. This process consists of preparing a suspension of $0.001 \%$ of fibers in approximately $700 \mathrm{~mL}$ of water, allowing it to hydrate for 4 hours, and then circulating the suspension in the analyzer. The images are generated by a laser beam and measured by an analyzer using Wshape software. Table 3 summarizes the characteristics of the material.

\subsection{Stirring vacuum de-watering technique}

The composites were produced by the stirring vacuum dewatering process with the dispersion of solid materials in a large volume of water (in concentrations around $20 \%$ of solids by mass), vacuum drainage to remove excess of water (negative manometric pressure of 60 to $80 \mathrm{kPa}$ ), and pressing at $3.2 \mathrm{MPa}$ for 5 minutes (Figures 2, 3 and 4).
The water/gypsum ratio - the difference in mass between the dry materials and the wet plate - was determined from the newly molded plates immediately after compression.

The plates were allowed to rest for 24 hours in the laboratory environment (at a temperature of $25^{\circ} \mathrm{C}$ and air humidity of $75 \%$ ), and then cured in a Termotron ${ }^{\circledR}$ chamber (at a temperature of $45^{\circ} \mathrm{C}$ and relative humidity of $75 \%$ ) until they attained a constant mass, which took 72 hours. Finally, the samples were dry-cut into $160 \times 40 \times 8 \mathrm{~mm}$ test specimens using a diamond disc saw (Figure 5).

\subsection{Mechanical behavior}

The samples' mechanical properties of the samples were analyzed based on flexural strength tests with four-point loading, following the recommendations of the RILEM Technical Committee 49 TFR $^{15}$.

Table 3. Characteristics of the cellulose fibers of Kraft cement bag (cel-cb).

\begin{tabular}{|c|c|c|c|c|c|c|c|}
\hline Pulp & $\begin{array}{c}\text { Average } \\
\text { length }(\mathrm{mm})\end{array}$ & $\begin{array}{c}\text { Average } \\
\text { width }(\mu \mathrm{m})\end{array}$ & $\begin{array}{l}\text { Aspect } \\
\text { ratio }\end{array}$ & $\begin{array}{l}\text { Coarseness } \\
(\mathrm{mg} / 100 \mathrm{~m})\end{array}$ & $\begin{array}{l}\text { Fibrous material/grams } \\
\text { (millions) }\end{array}$ & $\begin{array}{l}\text { Measured } \\
\text { objects }\end{array}$ & Fine* $(\%)$ \\
\hline cel-cb & 0.80 & 22.67 & 35 & 23.65 & 5.31 & 11.712 & 52.43 \\
\hline
\end{tabular}

*The fineness represents the percentage of fibers shorter than $0.07 \mathrm{~mm}$ of length, consequently, thus having a low capacity reinforcement of the matrix capacity.

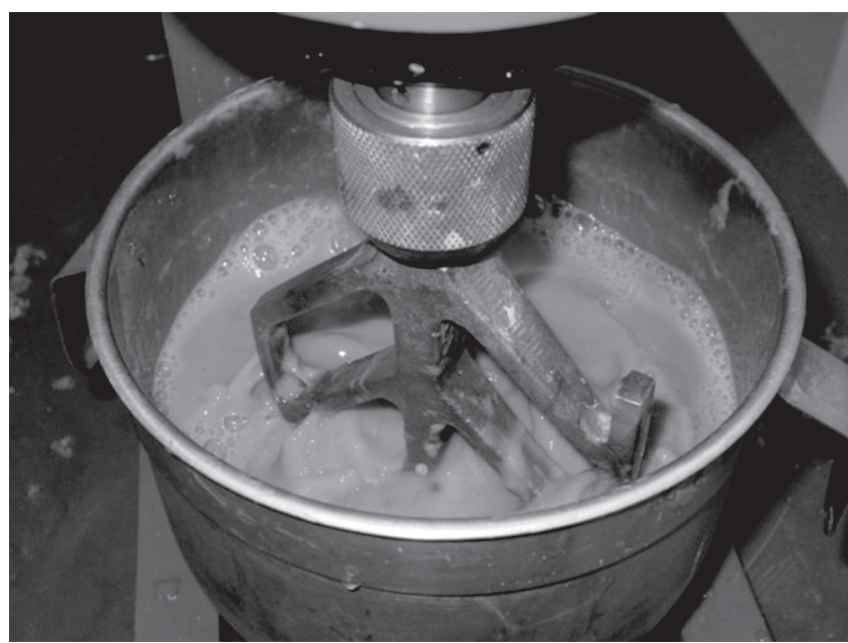

Figure 2. Mixing in the blender.

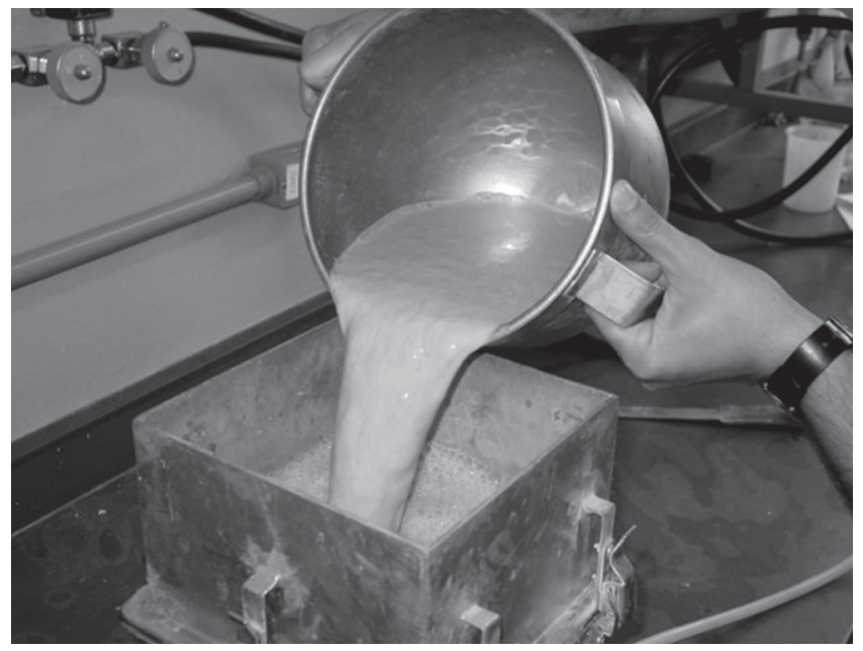

Figure 3. Mold.

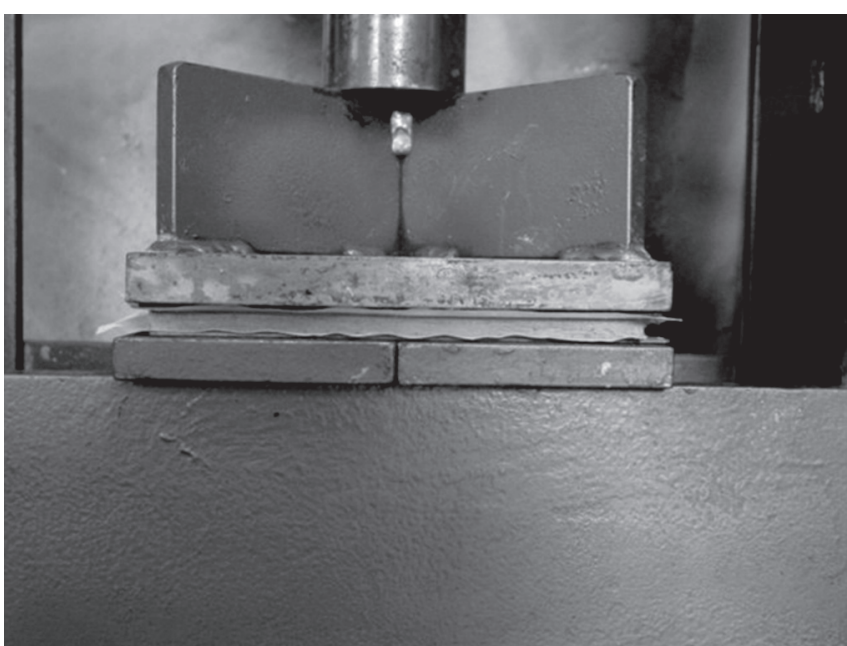

Figure 4. Mechanical pressing.

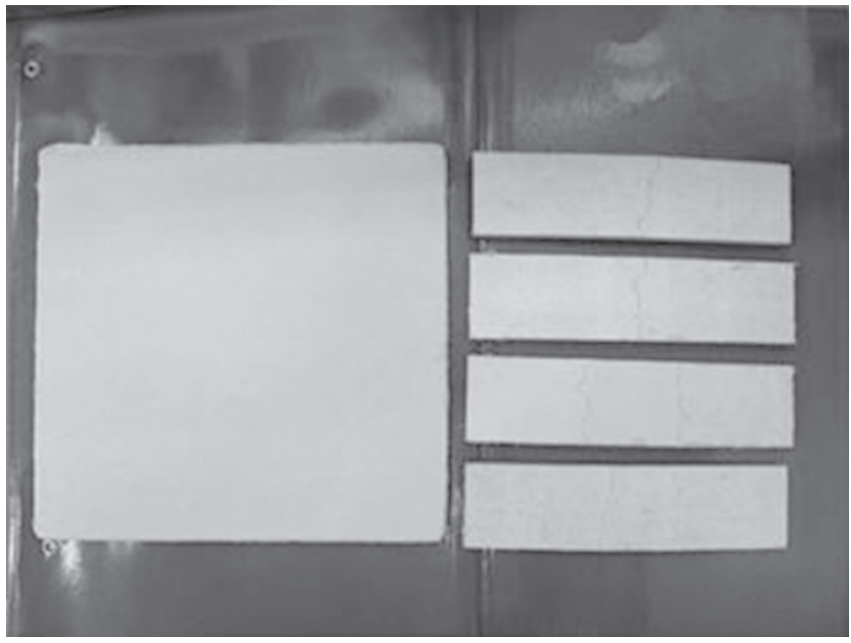

Figure 5. Cutting of the plates. 
A universal EMIC DL 30000 testing machine was used with a $5 \mathrm{kN}$ load cell and $1.5 \mathrm{~mm} / \mathrm{min}$ compression arm displacement. The flexural properties of the materials were measured 14 days after manufacture. The results were calculated from the arithmetic average of a series of 12 test specimens.

The modulus of rupture (MOR) was calculated by the software M-Tests version 1.01/96 and given by the expression (1):

$$
M O R=\frac{P_{\max } l v}{b e^{2}} \rightarrow M P a
$$

The limit of proportionality (LOP) is given by the expression (2):

$$
L O P=\frac{P_{L O P} \cdot l_{v}}{b \cdot e^{2}} \rightarrow M P a
$$

The fracture toughness $(\mathrm{T})$ was calculated by the integration of the load deflection curve to the point corresponding to a reduction in load carrying capacity to $50 \%$ of the maximum observed. It is given by the expression (3):

$$
T=\frac{\text { fracture energy }}{b . e} \rightarrow\left(k J / m^{2}\right)
$$

The modulus of elasticity (MOE) is given by the expression (4):

$$
M O E=\frac{276 \cdot l_{v}{ }^{3}}{1296 \cdot b \cdot e^{3}} \cdot \delta \rightarrow M P a
$$

where:

$p_{\max }=$ maximum load carried by the specimen $(\mathrm{N})$;

$P_{\text {LOP }}^{\max }=$ maximum applied load at which the load time (load-strain) curve deviates from linearity $(\mathrm{N})$;

$l_{v}=$ the support span $(\mathrm{mm})$;

$b=$ the specimen breadth (mm);

$e=$ the specimen depth (mm);

$\delta=$ angular coefficient of linear domain of load $\mathrm{x}$ displacement curve.

\subsection{Microstructure}

The fracture surfaces were analyzed from samples fractured in the flexural strength test, using images obtained by scanning electron microscopy (SEM) with secondary electrons (SE). The maximum magnification used here was 3000x. The work distance (distance from the microscope's lens to the test specimen) was about $20 \mathrm{~mm}$ and the accelerating voltage was $20 \mathrm{kV}$. The specimens were cut into prism shapes with $0.5 \times 0.5 \times 0.5 \mathrm{~cm}$ sides, attached to a sample holder and metallized with gold. The microscope used here was a Philips $^{\circledR}$ model XL 30 FEG coupled to an EDAX Link Isis system for microanalysis.

\subsection{Calorimetry}

A pseudo-adiabatic calorimetry technique similar to that employed by Murat \& Jeandot ${ }^{16}$, Hincapié \& Cincotto $^{17}$ and Antunes ${ }^{18}$ was applied to observe how the addition of limestone powder and cellulose pulp influenced the hydration of gypsum paste. This technique produces a temperature increment curve during the hydration of gypsum paste in relation to the beginning and end of the hardening process.

The variations in hydration-generated heat in the samples were measured with a pseudo-adiabatic calorimeter (Figure 6). The equipment consisted of a polystyrene foam cup to insulate the sample from room temperature, a thermocouple (copper-nickel), and Monitoring System Comtemp View ${ }^{\circledR}$ (version 1.05) software for temperature and time readings. The materials and equipment were kept in a room with temperature set at $22{ }^{\circ} \mathrm{C}$.

The sequence of the process was:

- 1 minute to add the gypsum powder to the pure water or to the water mixed with other materials (limestone and cellulose). The gypsum was poured into the insulated container through a funnel;

- 2 minutes for the gypsum powder to dissolve;

- 1 minute to homogenize the material (using a blade), and end of the mixing process; and

- Passive reading by the software.

The following samples were produced in this process: NG100 (composed of 100\% natural gypsum); NG90+limestone (90\% natural gypsum and $10 \%$ limestone); NG90+cel-cb (90\% natural gypsum and $10 \%$ cel-cb); and NG80+limestone+cel-cb (80\% natural gypsum, $10 \%$ limestone and $10 \%$ cel-cb).

\section{Results and Discussion}

\subsection{Flexural behavior}

Figure 7 and 8 depicts the strain displacement curves of the composites. The test specimens were composed of natural gypsum

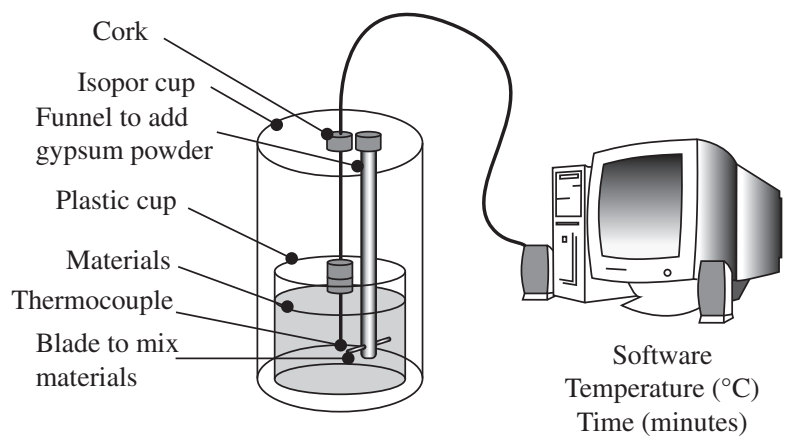

Figure 6. Pseudo-adiabatic calorimeter - equipment used in the laboratory to study the kinetics of gypsum hydration.
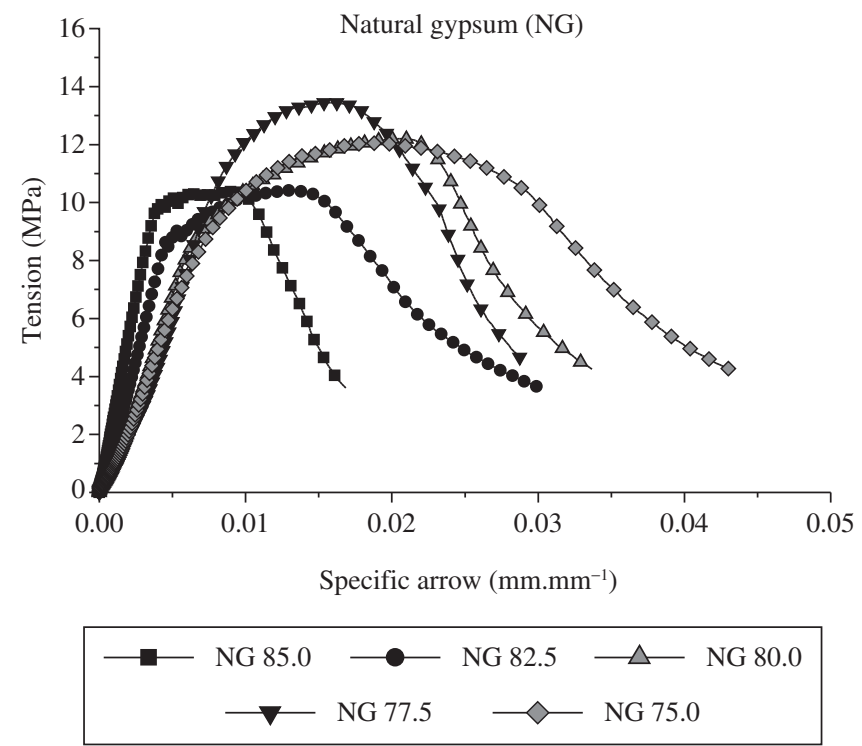

Figure 7. Strain displacement curves of matrices made of natural gypsum. 
(NG), recycled gypsum (RG), 10\% of added limestone, and different percentages $(5,7.5,10,12.5$, and 15\%) of Kraft cement bag pulp (celcb), and a reference sample without pulp.

The suction and compression-molding process produced composites with high mechanical performance. All the cellulose pulp waste (cel-cb) percentages improved the composites' mechanical performance. Composites containing $5 \%$ of pulp exhibited a two-fold improvement in performance, but the specimens with $12.5 \%$ of pulp (cel-cb) presented the highest flexural strength. Composites RG77.5 and NG77.5, with a 12.63 and $13.18 \mathrm{MPa}$ modulus of rupture (MOR), presented an increase in resistance of $152 \%$ and $163 \%$, respectively, compared to their counterparts without fibers, whose modulus of rupture was about 5.00 $\mathrm{MPa}$ (Table 4).

The specimens containing $12.5 \%$ of pulp (cel-cb) also presented the highest limit of proportionality (LOP), which is another indication that this was the ideal content. Under continuous loading, the LOP

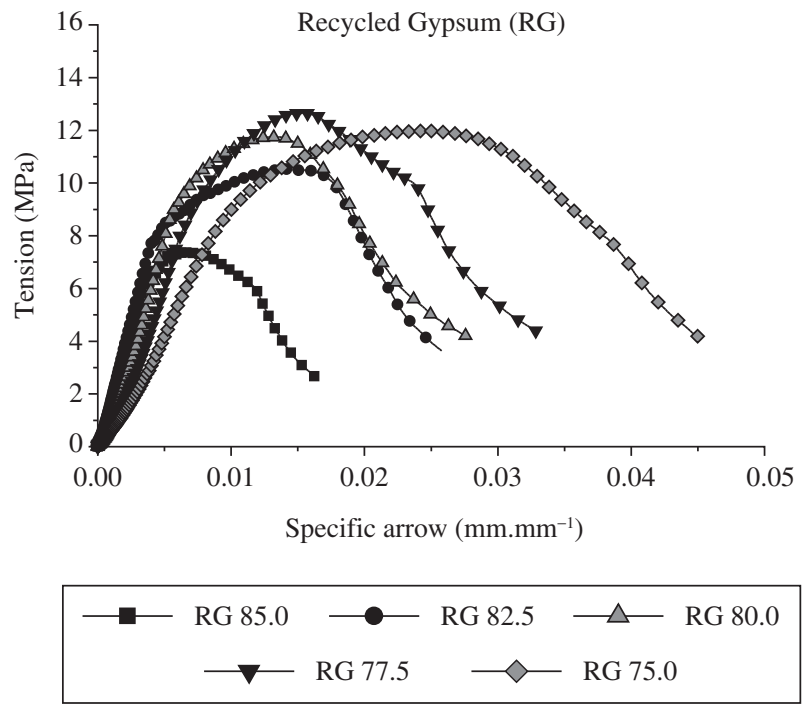

Figure 8. Strain displacement curves of matrices made of recycled gypsum indicates the maximum stress attained before the material exceeds the elastic state, i.e., before deviating from its linearity.

Table 4 indicates the absence of a direct correlation between increased mechanical strength and loss of toughness. With a pulp content of to $12.5 \%$, the material showed an increase in toughness concomitant to the increase in the MOR.

\subsection{Microstructure}

The morphology of the gypsite crystals is the result of the conditions of paste hydration. Images of the composites molded by suction and compression exhibited significant variations in crystal size.

Compared with samples without pulp, the samples containing $10 \%$ of pulp showed varying gypsite crystal sizes around the fibers (Figure 9 and 10), although they maintained their original needle shape and arrangement. Dihydrate crystals are predominantly needleshaped. The larger size of the crystals surrounding the fibers may be attributed to the number, shape and hydrophilic characteristics of the

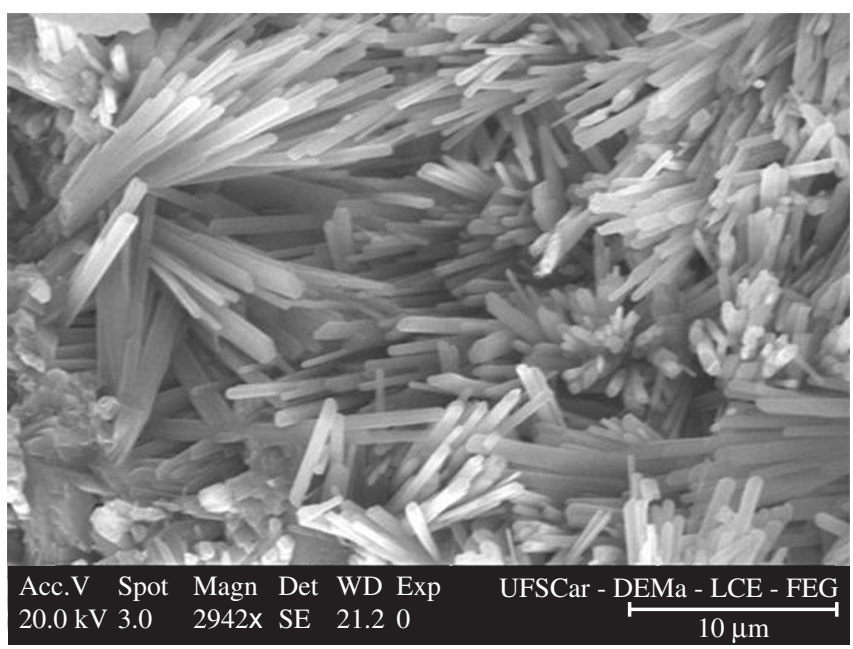

Figure 9. SEM and secondary electron images. Matrix without fibers.

Table 4. Average values of the composites' mechanical properties.

\begin{tabular}{|c|c|c|c|c|c|c|c|c|c|c|c|c|}
\hline \multicolumn{3}{|c|}{ Composite } & \multicolumn{2}{|c|}{ Water/gypsum ratio } & \multicolumn{2}{|c|}{ MOR (MPa) } & \multicolumn{2}{|c|}{$\mathrm{LOP}(\mathrm{MPa})$} & \multicolumn{2}{|c|}{$\mathrm{T}\left(\mathrm{kJ} \cdot \mathrm{m}^{-2}\right)$} & \multicolumn{2}{|c|}{$\mathrm{MOE}(\mathrm{GPa})$} \\
\hline 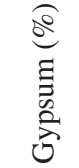 & 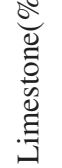 & 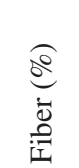 & NG & RG & NG & RG & NG & RG & NG & $\mathrm{RG}$ & NG & $\mathrm{RG}$ \\
\hline 90.0 & 10 & - & $\begin{array}{c}0.20 \\
(0.01)\end{array}$ & - & $\begin{array}{c}5.00 \\
(0.75)\end{array}$ & - & $\begin{array}{c}4.48 \\
(1.00)\end{array}$ & - & $\begin{array}{c}0.09 \\
(0.05)\end{array}$ & - & $\begin{array}{c}9.67 \\
(0.58)\end{array}$ & - \\
\hline 85.0 & & 5.0 & $\begin{array}{c}0.27 \\
(0.01)\end{array}$ & $\begin{array}{c}0.32 \\
(0.01)\end{array}$ & $\begin{array}{l}10.09 \\
(1.25)\end{array}$ & $\begin{array}{c}7.75 \\
(0.86)\end{array}$ & $\begin{array}{c}9.03 \\
(0.87)\end{array}$ & $\begin{array}{c}6.33 \\
(0.96)\end{array}$ & $\begin{array}{c}0.80 \\
(0.13)\end{array}$ & $\begin{array}{c}0.74 \\
(0.20)\end{array}$ & $\begin{array}{c}9.58 \\
(0.97)\end{array}$ & $\begin{array}{c}7.43 \\
(0.79)\end{array}$ \\
\hline 82.5 & & 7.5 & $\begin{array}{c}0.35 \\
(0.01)\end{array}$ & $\begin{array}{c}0.34 \\
(0.01)\end{array}$ & $\begin{array}{c}9.71 \\
(1.10)\end{array}$ & $\begin{array}{l}10.57 \\
(0.80)\end{array}$ & $\begin{array}{c}6.97 \\
(1.35)\end{array}$ & $\begin{array}{c}8.25 \\
(0.82)\end{array}$ & $\begin{array}{l}1.70 \\
(0.43)\end{array}$ & $\begin{array}{c}1.47 \\
(0.44)\end{array}$ & $\begin{array}{c}5.94 \\
(0.93)\end{array}$ & $\begin{array}{c}6.69 \\
(0.53)\end{array}$ \\
\hline 80.0 & & 10.0 & $\begin{array}{c}0.36 \\
(0.01)\end{array}$ & $\begin{array}{c}0.37 \\
(0.01)\end{array}$ & $\begin{array}{l}12.42 \\
(1.17)\end{array}$ & $\begin{array}{l}11.97 \\
(0.92)\end{array}$ & $\begin{array}{c}9.21 \\
(1.26)\end{array}$ & $\begin{array}{c}9.20 \\
(0.56)\end{array}$ & $\begin{array}{c}2.10 \\
(0.28)\end{array}$ & $\begin{array}{c}1.86 \\
(0.49)\end{array}$ & $\begin{array}{c}5.92 \\
(0.85)\end{array}$ & $\begin{array}{c}5.98 \\
(0.45)\end{array}$ \\
\hline 77.5 & & 12.5 & $\begin{array}{c}0.37 \\
(0.02)\end{array}$ & $\begin{array}{c}0.39 \\
(0.01)\end{array}$ & $\begin{array}{l}13.18 \\
(1.34)\end{array}$ & $\begin{array}{l}12.63 \\
(0.45)\end{array}$ & $\begin{array}{c}9.91 \\
(1.48)\end{array}$ & $\begin{array}{c}9.15 \\
(0.56)\end{array}$ & $\begin{array}{c}2.27 \\
(0.33)\end{array}$ & $\begin{array}{c}2.39 \\
(0.34)\end{array}$ & $\begin{array}{c}5.58 \\
(0.89)\end{array}$ & $\begin{array}{c}5.05 \\
(0.34)\end{array}$ \\
\hline 75.0 & & 15.0 & $\begin{array}{c}0.40 \\
(0.02) \\
\end{array}$ & $\begin{array}{c}0.43 \\
(0.01) \\
\end{array}$ & $\begin{array}{l}11.66 \\
(1.50) \\
\end{array}$ & $\begin{array}{l}12.15 \\
(0.77) \\
\end{array}$ & $\begin{array}{c}7.84 \\
(1.26) \\
\end{array}$ & $\begin{array}{c}8.47 \\
(0.60)\end{array}$ & $\begin{array}{c}3.46 \\
(0.78) \\
\end{array}$ & $\begin{array}{c}3.24 \\
(0.62)\end{array}$ & $\begin{array}{c}3.88 \\
(6.10) \\
\end{array}$ & $\begin{array}{c}4.18 \\
(0.50)\end{array}$ \\
\hline
\end{tabular}

(Standard deviation);

MOR (modulus of rupture); LOP (limit of proportionality); T (fracture toughness);

MOE (modulus of elasticity); RG (recycled gypsum); and NG (natural gypsum). 
fibers, and hence, to the increase in the water/gypsum ratio in the proximities of the fibers.

Confirming the superiority of the suction/compression process evidenced in the rupture modulus and toughness results, the simultaneous presence of fiber pullout and fractures indicates the good level of fiber-matrix adhesion (Figure 11).

Crystal incrustations on fiber surfaces and fractured layers with pulled out filaments indicate that the combined work of the phases improves the composite's performance. The cel-cb waste fiber presented good adhesion to the matrix.

\subsection{Calorimetry}

Unlike the pastes without cellulose (NG100) and (NG90+limestone), the pastes containing $10 \%$ of cellulose pulp (NG90+cel-cb) and (NG80+limestone+cel-cb), Figure 12, contributed to increase the "induction time" of the paste, i.e., the time elapsed from the gypsum's dilution in water to the solution's saturation, which was almost doubled. These results confirm data reported by Zhang ${ }^{19}$ and Simatupang \& Smith ${ }^{20}$, whose studies on the action of wood extracts on the setting of gypsum plates found that some substances released by natural fibre fiber in aqueous solution (lignins, resins, polyphenols, oils and fats) interfere in the kinetics of gypsite crystal formation. Cellulose pulp acts as a retardant in the setting process, increasing the induction period and causing displacement of the hydration heat curve of the gypsum paste. In the traditional gypsum paste production and application process, the concept of "useful time" comprises the period from the beginning to the end of the setting time.

Figure 12 illustrates the hydration heat curves (pseudo-adiabatic calorimetry).

The addition of limestone powder did not appear to affect the formation rate of the crystalline gypsite structure, as indicated in Table 5, where the beginning and end of the setting (or hardening)

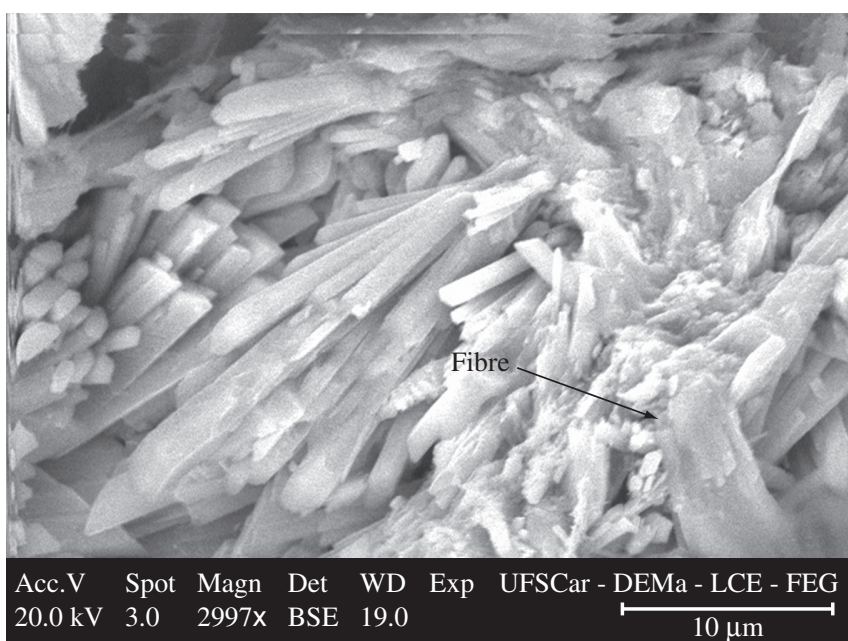

Figure 10. SEM and secondary electron images. Matrix containing $10 \%$ of cellulose pulp.

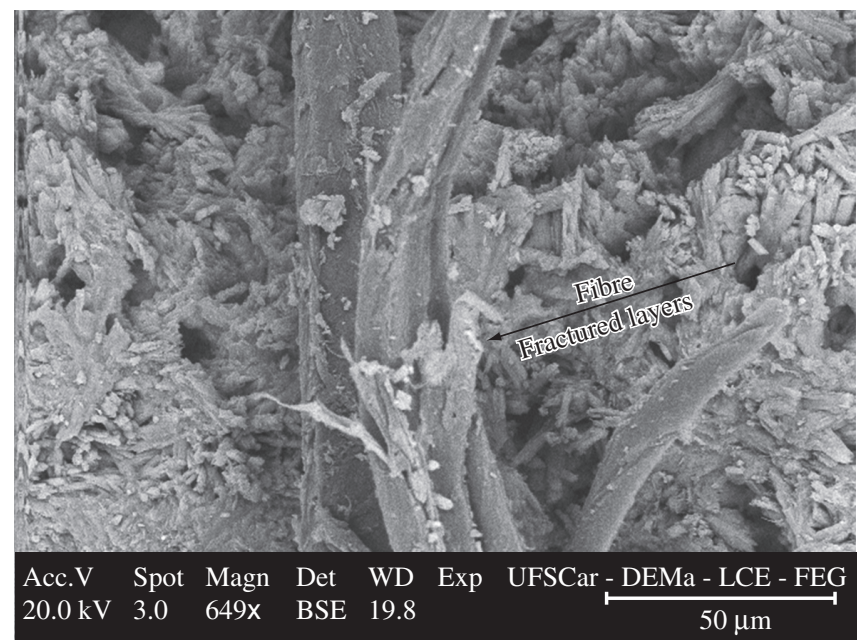

Figure 11. SEM image of fractured fibers.

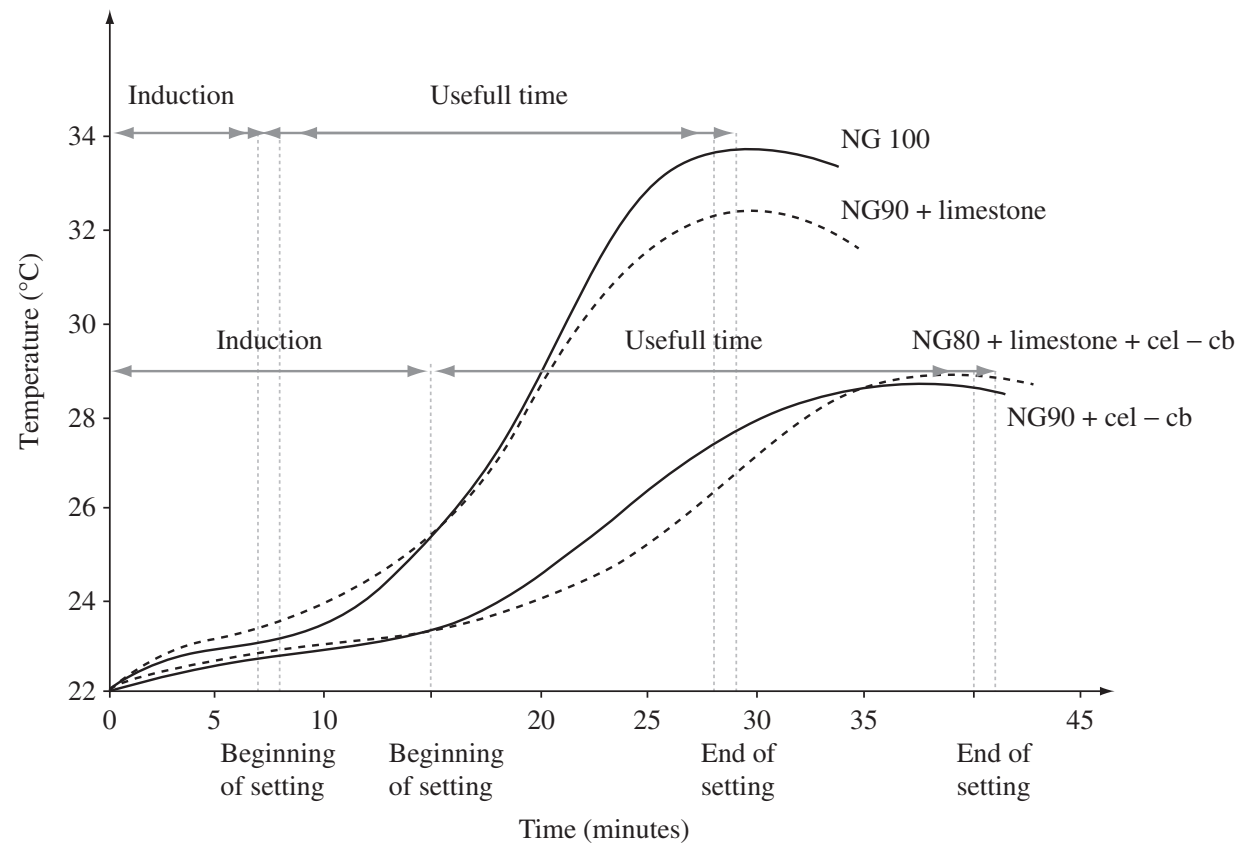

NG100 (100\% of natural gypsum

NG90 + limestone $(90 \%$ of natural gypsum and $10 \%$ of limestone);

$\mathrm{NG} 90+\mathrm{cel}-\mathrm{cb}(90 \%$ of natural gypsum and $10 \%$ of cel $-\mathrm{cb}$ );

$\mathrm{NG} 80+$ limestone $+\mathrm{cel}-\mathrm{cb}(80 \%$ of natural gypsum and $10 \%$ of limestone and $10 \%$ of $\mathrm{cel}-\mathrm{cb}$ )

Figure 12. Hydration heat curves obtained with a pseudo-adiabatic calorimeter. 
Table 5. Hydration time of the pastes with and without cellulose pulp, and with and without limestone powder.

\begin{tabular}{lcccc}
\hline Time (minutes) & \multicolumn{3}{c}{ Pastes } \\
\cline { 2 - 5 } & NG & NG+limestone & NG+cel-cb & NG+limestone+cel-cb \\
\hline Beginning of the hardening process & 7 & 8 & 15 & 15 \\
End of the hardening process & 28 & 29 & 40 & 41 \\
\hline
\end{tabular}

time and the useful time were practically identical in the samples with and without cellulose. Based on our experimental results, it can be concluded that the limestone powder acted effectively in reducing the water's surface tension, improving the dispersion of the gypsum mineral and cellulose pulp particles.

\section{Conclusions}

Compared to the conventional procedure of gypsum plate production, the suction/compression molding process produced composites with high mechanical performance.

The addition of Kraft pulp waste changed the kinetics of gypsum hydration. Comparing gypsum pastes without cellulose pulp (NG 90) to the corresponding pastes with cellulose pulp (NG 80), it is possible to conclude that the cellulose pulp contributed to the increase of induction times in approximately $100 \%$. The natural fibers absorbed and retained a larger amount of water in the matrix, enabling the formation of larger crystals in their proximities. Moreover, the fibers adhered satisfactorily to the gypsum matrix.

All the studied amounts of cellulose pulp waste improved the composites' mechanical performance of the composites. The best results were obtained with $12.5 \%$ by mass of cellulose pulp. The specimens with $12.5 \%$ of pulp (cel-cb) presented the highest values of modulus of rupture (MOR) around $13 \mathrm{MPa}$ which represent an increase in resistance of $160 \%$ approximately compared to their counterparts without fibers.

The stirring vacuum de-watering process originated composites with high mechanical performance. This material is a technically better substitute for brittle gypsum plate, and stands out particularly for its characteristics of high impact strength and high modulus of rupture.

\section{Acknowledgements}

The authors are indebted to Furnas Centrais Elétricas' Chemistry Laboratory, to the Construction and Ambiance Laboratory of the University of São Paulo at Pirassununga (FZEA-USP) School of Animal Science and Food Engineering, and to the Pulp and Paper Laboratory of the Federal University of Viçosa's Department of Forest Engineering, MG, for carrying out the tests. Special thanks are also due to Sérgio Santos, Gustavo Tonoli, Zaqueu Dias, Ronaldo Teixeira and José Wilson Nerys for their unstinting help and encouragement.

\section{References}

1. Agopyan V, Souza UEL, Paliari JC, Andrade AC. Alternativas para redução do desperdício de materiais nos canteiros de obras. São Paulo; 1998.

2. Moslemi AA. Emerging technologies in mineral-bonded wood and fiber composites. Advanced Performance Materials 1999; 6(2):161-179.

3. Savastano-Jr H, Agopyan V. Transition zone studies of vegetable fibrecement paste composites. Cement and Concrete Composites 1999; 21(1):49-57.

4. Agopyan V. Vegetable fibre reinforced building materials - developments in Brazil and other Latin American countries. In: RN Swamy (Ed).
Natural fibre reinforced cement and concrete. Concrete and Technology and Design. Glasgow: Blackie; 1988.

5. Savastano-Jr H, Warden PG, Coutts RSP. Microstructure and mechanical properties of waste fibre-cimente composites. Cement and Concrete Composites 2005; 27(5):583-592.

6. Gram HE. Durability of natural fibres in concrete. In: Swamy RN. (Ed). Natural fibre reinforced cement and concrete. Glasgow: Blackie; 1988.

7. Guimarães SS. Vegetable fiber-cement composites In: 2 International symposium on vegetable plants and their fibres as building materials; 1990; Salvador. London: Chapman and Hall; 1990. p. 98-107.

8. Savastano-Jr H, Warden PG, Coutts RSP. Brazilian waste fibres as reinforcement for cement-based composites. Cement and Concrete Composites 2000; 22(5):379-384.

9. Jeulin D, Monnaie P, Péronnet F. Gypsum morphological analysis and modeling. Cement and Concrete Composites 2001; 23(2):299-311.

10. Ridge MJ. Effect of Temperature on the Rate of Setting of Gypsum Plaster. Nature 1959; 184:47-48.

11. ASSOCIAÇÃO BRASILEIRA DE NORMAS TÉCNICAS - ABNT. NBR 13207. Gesso para construção civil-especificação. Rio de Janeiro; 1994.

12. BRITISH STANDARD INSTITUITION. BS 1191: Part 1. Specification for gypsum building plasters. London; 1973.

13. ASSOCIATION FRANÇAISE DE NORMALIZATION. AFNOR NF B 12-300. Plâtres: generalités clauses et conditions generals. França; 1963.

14. Cincotto MA, Agopyan V, Florindo MC. O gesso como material de construção - composição química ( $1^{\mathrm{a}}$ parte). In: Tecnologia de edificações. São Paulo: Pini; 1988.

15. RILEM. Technical Committee 49 TFR - Test for the determination of modulus of rupture and limit of proporcionality of thin fibre reinforced cement section - Materiaux et Constructions 1984; 17(102):441-451.

16. Murat M, Jeandot G. Méthodes de measures et interpretation des effets thermiques associés à 1'hydratation des sulfates de calcium et des plâtres industrieils. Revue de Matérials and Building Research 1979, $1: 264-271$

17. Hincapié AM, Cincotto MA. Efeito de retardadores de pega no mecanismo de hidratação e na microestrutura do gesso de construção. Ambiente Construído 1997; 1(2):07-16.

18. Antunes RPN. Estudo da influência da cal hidratada nas pastas de gesso. [Dissertação de Mestrado em Engenharia Civil] São Paulo: Universidade de São Paulo; 1999.

19. Zhang, Y. Influence of wood extractive on hardening and properties of gypsum plaster and gypsum bonded particleboard. Beijing: Wood Industry; 1990.

20. Simatupang MAH, Schmitt U. Wood extractives of rubberwood (Hevea brasiliensis) and their influences on the setting of the inorganic binder in gypsum-bonded particleboards. Journal of Tropical Fores [16] t Science 1994; 6(3):269-285. 